\title{
The implementation of effective communication principles in the tuberculosis cadre re-training activity
}

\author{
Windu Santoso $^{1 *} ;$ Sri Sudarsih ${ }^{2}$ \\ ${ }^{\text {*); } 2}$ Sekolah Tinggi Ilmu Kesehatan Bina Sehat PPNI
}

\section{ARTICLE INFO}

Article history:

Received May 26, 2019

Revised June 25, 2019

Accepted July 13, 2019

\section{Keyword:}

Communication

Training

Social worker in health

Tuberculosis

*) corresponding author

Sekolah Tinggi Ilmu Kesehatan Bina Sehat PPNI

Jln. Raya Jabon KM 06 Mojokerto Jawa Timur

Email: windusantoso36@gmail.com

DOI: https://doi.org/10.30604/jika.v4i2.202

\begin{abstract}
A B S T R A C T
Effective communication is one of the abilities that must be possessed by TB cadres (tuberculosis) in carrying out their duties. This ability must always be honed so that we need a form of retraining to improve communication skills in providing counseling and training in the community. This research aims to measure the effective communication skills of TB cadres (tuberculosis) in the Re-Training Activity which is carried out for 4 days. The method used in this research is descriptive. Retrieval of data with an observation sheet in the form of a checklist designed according to seven components in effective communication. The population was all TB cadres who participated in the Re training and a sample of 27 cadres. The results showed 59.3\% had effective communication skills. Based on the criteria of effective communication on the criteria of the suitability of messages with the needs of respondents, the use of communion channels, empathy is above $81.5 \%$, while the components of message clarity, completeness of planning and organizing messages, feedback and understanding of messages as well as the contents of messages delivered on average still not enough. The results of this research are very useful as a basis for determining the follow up of cadre re training so that cadres will be more trustworthy and able to improve their abilities in carrying out their duties.
\end{abstract}

This is an open access article under the CC-BY-SA license.

\section{INTRODUCTION}

Tuberculosis (TB) is a contagious infectious disease caused by the bacterium Mycobacterium Tuberculosis, this bacterium can attack various organs especially the lungs. TB disease if not treated or the treatment is not complete it will cause dangerous complications until death. There are several indicators that can be used to assess the success of TB control programs, which are mainly indicators of case finding, treatment indicators and treatment success rates (Ministry of Health, 2015). Since the 
first TB case was reported in Indonesia, various efforts have been made by the government through the ministry of health. These efforts began with the process of suspecting screening, detecting and recording cases, treating patients, and managing multi drug resistance (MDR) Tuberculosis (Infodatin, 2018).

Referring to Minister of Health Regulation No. 67 of 2016 article 2 that tackling tuberculosis involves all relevant parties both government, private and community in the form of district / city-based PPM (Public Private Mix) collaboration network (KNCV, 2018). Through the Tuberculosis Prevention Program (TB), 'Aisyiyah strives to participate in health development in Indonesia and achieve the Millennium Development Goals (MDGs) target no. 6, namely a decrease in the spread of infectious diseases. As the mandate of the Congress and Tanwir isy Aisyiyah, TB prevention efforts were carried out both in areas that received support from donor agencies and independently. Therefore the TB Control Program (Community TB Care) 'Aisyiyah continues to be developed in 33 provinces in Indonesia (Aisyiyah, 2017).

Aisyiyah who acts as Principal Recipient (PR) in PR TB Aisyiyah through cadres in the community is very important in efforts to find TB cases that have been difficult to disclose (Suara Muhammadiyah, 2019). The cadres are expected to be able to approach humanity with the community, when seeking suspects, bringing them to be examined at the health center until it is known whether positive or not. A cadre is expected to be able to carry out his duties as a TB cadre, communicate effectively, and carry out TB recording and reporting (Dinkes, 2013).

The ability to communicate effectively with others is an important skill. Through communication, people can understand each other's understanding, learn to like each other, influence each other, build trust, and learn more about themselves and how people understand others. People who communicate effectively know how to interact with others flexibly, skillfully and responsibly, but without compromising their own needs and integrity.

The national target of the National Medium Term Development Plan (RPJMN) set out in Presidential Regulation No. 59 of 2017 concerning SDGs sets the target of TB prevalence in 2019 to 245 per 100,000 population. While the TB prevalence in 2014 was 297 per 100,000 population. Whereas in Permenkes Number 67 of 2016 concerning Tuberculosis Prevention, the target of the national TB Control program is elimination in 2035 and Indonesia Free of TB in 2050. TB elimination is the achievement of the number of TB cases 1 per 1,000,000 population. In 2017 the number of TB cases was 254 per 100,000 or 25.40 per 1 million population. The number of new TB cases in Indonesia was 420,994 cases in 2017 (data as of May 17, 2018) (Infodatin, 2018).

Communication has an important role in every action that aims to improve health. A message cannot be delivered to promote healthy choices if a cadre is unable to communicate, especially effective communication (Corcoran, 2007). Communication is considered a basic tool in health care relationships. The quality of communication has a strong relationship with its effectiveness (Grant, 2009). The ability to communicate effectively at work, at home, and in life is one of the most important skills a person needs (Akilandeswari, Kumar, Freeda, \& Kumar, 2015).

Effective communication must pay attention to the whole process, not only the content of the message, but also must consider the potential obstacles at several stages in communication. (Cohn, 2019). One way to improve effective communication skills is through communication training which generally aims to review the complexity of communication and to identify and interpret structures, processes, problems and dysfunctions so that they can suggest alternative procedures for improvement 
(Rickheit \& Strohner, 2008). The purpose of this research was to determine the picture of the effective communication skills of TB cadres (Tuberculosis) in $\mathrm{Re}$ Training activities based on the seven components of effective communication.

This research was conducted at the tuberculosis cadre training activity held by Aisha as a continuation of the previous training, and the researcher measured the communication of the trainees during role play. Researchers only observed the $\mathrm{Re}$ Training activity and did not take special treatment of respondents.

\section{METHOD}

The research design is descriptive. The research variable is the ability of cadres in effective communication The research population is all cadres of TB Aisyiyah in Mojokerto city as many as 27 people. Samples were taken by total sampling technique. Data were collected with an observation sheet instrument and analyzed using a frequency distribution. The observation sheet was developed by researchers based on the concept of effective communication theory. Observations made by researchers directly on respondents in retraining for 4 days. In this tuberculosis cadre re-training activity, the majority of participants had received training on tuberculosis in the previous stage. But the focus material is related to tuberculosis. Respondents were divided into three small groups to do role play in groups of the fourth day. During the observation the researcher was assisted by 6 observers who had previously made the same perception. Researchers conducted observations on 7 components of effective communication consisting of components of the clarity of the message to be conveyed, the completion of the planning and organizing the message, the message delivered, feedback (understanding of the message), empathy attitude, the suitability of the message with the needs of the audience and the use of communication channels. This research was conducted on April 29 to May 3, 2019 in Aisyiyah, Mojokerto City. During the Re-training, respondents received material about tuberculosis control policies, basic information about tuberculosis, the relationship of tuberculosis to HIV, the role of cadres in the discovery and assistance of tuberculosis patients, contact investigations, cadre empowerment, effective communication and counseling.

\section{RESULTS AND DISCUSSION}

Table 1

Respondent Characteristics Based On Age Of Experience And Frequency Of Training

\begin{tabular}{lcc}
\hline \multicolumn{1}{c}{ Respondent Characteristics } & f & $\%$ \\
\hline Age of Respondents & & \\
31-40 year & 7 & 25,9 \\
$41-50$ year & 17 & 63,0 \\
$51-60$ year & 3 & 11,1 \\
\hline Experience of Becoming A Cadre & & \\
$\quad<2$ year & 9 & 34 \\
$\geq 2$ year & & 66 \\
\hline Training Frequency & 3 & 11,1 \\
1 time & 24 & 88,9 \\
\hline 2 times & & \\
\hline
\end{tabular}


In this research the dominant respondents were aged $41-50$ years by $63 \%$, experience>
2 years, $66 \%$ and $88.9 \%$ had attended $>2$ times training as TB cadres (tuberculosis)

Table 2

Description Of The Ability's Respondents Based On Effective Communication Components

\begin{tabular}{lcc}
\multicolumn{1}{c}{ Effective Communication Components } & f & $\%$ \\
\hline The clarity message to be conveyed & 15 & 54.0 \\
Completeness, planning and organizing messages & 17 & 64,2 \\
Message delivered & 9 & 32,1 \\
Feedback & 5 & 18,5 \\
Empathy & 22 & 81,4 \\
The fit of the message with the needs of the audience & 25 & 92,6 \\
Use of Communication Channels & 24 & 88,9 \\
\hline
\end{tabular}

It can be said that based on the criteria of effective communication on the criteria of conformity of messages with the needs of respondents, the use of communion channels, empathy above 81, 5\%, while the components of message clarity, completeness of planning and organizing messages, feedback and understanding of messages as well as the contents of messages delivered the average is still lacking.

Table 3

Description Of The Ability's Effective

Communication Components On Implementing Cadre Re-Training

\begin{tabular}{lcc}
\hline \multicolumn{1}{c}{ Communication } & Frequency & $\boldsymbol{\%}$ \\
\hline Effective & 16 & 59,3 \\
Ineffective & 11 & 40,7 \\
\hline \multicolumn{1}{c}{ Total } & 27 & 100 \\
\hline
\end{tabular}

It can be said that the TB cadre Re-Training participants who were able to communicate effectively as a whole based on all components of effective communication reached $59.3 \%$.

All respondents in this research were female and the majority were 41-50 years old, experience becoming TB cadres (tuberculosis)> 2 years and attending > 2 times training as TB cadres (tuberculosis). Previous research has shown that diversity in age, sex, and ethnicity or race largely determines communication (Cohn, 2019). Respondents in this research are quite mature when seen from the age range, and it is very possible to be able to communicate effectively. The experience of becoming a cadre whose majority is more than 2 years and has gained several times is sufficient provision for cadres in carrying out their duties.

This research shows that more than half of the respondents are effective on the clarity component of the message to be conveyed. And $25.9 \%$ of respondents were effective in non-verbal communication, for example the use of hand signals during role play. Communication is central to human and organizational success. The ability to communicate effectively is one of the most important set of skills a person needs. Effective communication is a life skill and the most important source of personal strength at work, family and social situations. Communication is the process of understanding and being understood through ideas, facts, thoughts, and emotions. Good communication is determined not by how well we say something, but how well we are understood. Communication is the process through which messages are delivered to a person or group of people. If the message is delivered clearly and unambiguously, and is received by the recipient in the same manner 
as intended by the sender, then the communication is said to be effective. If the message reaches the recipient in a distorted form or somehow fails to create meaning or understanding, the communicator must realize that his communication has been affected by obstacles. So we can say that communication is successful only if the recipient understands what the sender is trying to say. Feedback received by the sender from the receiver allows the sender to determine how the message is interpreted (Akilandeswari et al., 2015).

Effective communication is one of the success factors in interacting with the environment. Effective or not communication that we do depends on how understanding the recipient of the message to the message we have conveyed. So that the message we convey can be understood by others, there are several things that need to be considered, one of which is the clarity of the message delivered. Respondents in this research try to give a message clearly, this can be seen when delivering a message most respondents can use communication clearly, speak at the right speed so that the message is easily understood, can clearly describe the message conveyed to the interlocutor with confidence self and the use of language or sentences that are easily understood by the recipient of the message.

This research proves that the majority of respondents are effective in the components of completeness, planning, and organizing messages. Components Completeness, planning and organizing messages are one of the stages in creating effective communication (Management, 2013). Effective communication can succeed if it is prepared and managed well. In this research, most respondents started and ended communication by giving greetings to the interlocutors, using open-ended questions to find out the facts and reducing the use of inappropriate examples and only $48 \%$ of respondents used too many ideas in communication.
Based on the message components used indicate that the majority of respondents have been effective. Similarly, the components of the use of communication channels found that most respondents were already effective.

The message is a stimulus produced by the sender and responded by the recipient. Messages can be verbal, nonverbal, written material, etc. (Berman, 2016). The message is the content of communication that embodies any information package that the communicator wants to convey or exchange with others. Message as a mindset, configuration of ideas, or other responses to internal conditions about which individuals are expressing themselves. However, such expressions presuppose several forms of behavioral manifestations: thoughts and feelings, in order to be known, must be coded or organized into physical forms that are capable of being transmitted to others (Salija, Muhayyang, \& Rasyid, 2018).

Message and communication are two things that have interrelated relationships. In communication messages are the main elements that must exist in communication. The message is the whole of what is conveyed by the communicator and has a core message or theme as an influence in trying to change the communicant's attitudes and behavior. Messages can be delivered in various forms and must pay attention and be directed and appropriate delivery methods in accordance with the purpose of the delivery of the message. In this research, most respondents used the right words to influence the interlocutor and provide motivation, only a small proportion of respondents who repeated the conversation and who used sentences that were too long and difficult to understand. Respondents in this research were mostly able to use intonation appropriately, speaking in an appropriate tone not too loud and not too soft.

The results of this research indicate that based on the components of feedback and understanding of messages only a small proportion of respondents whose messages 
are less understood by the interlocutor. And based on the component of the suitability of the message used in effective communication shows that most respondents were effective.

Feedback is a benchmark that measures the effectiveness of communication (Management, 2013). Feedback is information the sender receives about the recipient's reaction to the message. The function of feedback is to give the sender information about the recipient's perception of a situation. With this information, the sender can then adjust the sending of the message to communicate more effectively. Communication is reciprocal because the sender and receiver must be involved; the sender must send a message, and the recipient must provide feedback for communication to be complete. The attached screen lists the characteristics of effective feedback (Berman, 2016). Through feedback, the sender can assess the extent to which the message has been successfully received and its impact. Monitoring the recipient's reaction allows communication to be further adjusted and regulated to achieve the desired effect. Therefore, feedback is very important for successful communication outcomes (Salija et al., 2018).

Effective or not communication can be seen from the feedback (feedback). Feedback is a message given by a recipient when a message giver is delivering his message. Feedback arising from the communication process gives a picture to the communicator about the results of the communication it does. Feedback is an element that can see whether the communication that has been successful or failed. In this research, only a small proportion of respondents whose messages were less understood by the interlocutor showed that most of the respondents conveyed their messages well so that they received appropriate feedback from the interlocutor when communicating. This can be seen when the interlocutor (communicant) gives feedback in the form of questions, communicants use questions that are right on target or in accordance with what the communicator wants to achieve.

The results of the research on the components of empathy attitude found that the majority of respondents showed an attitude of empathy when communicating. Empathy is the ability to project oneself to the conditions and feelings of others. Empathy comes from empathy, which means to feel. In communication, empathy is very important so that messages can be received effectively and appropriately. Therefore communicators and communicants need to build empathy to be able to feel and be involved psychologically, feeling and condition of each party (Palupi, Hidayat, Subiyantini, \& Rizki, 2016). Eye contact that uses the eye senses that function as a mirror of the soul. As a mirror of the soul, they reflect the main decision factor in interpreting the words spoken. The eye can describe the most powerful and revealing body language - the truth can always be found in the eye, regardless of verbal messages and facial expressions that come out. The eye can accurately signify positive or negative feelings and thoughts (Salija et al., 2018).

One communication strategy that can be used by communicators is to apply empathy. Through the application of empathy, we can feel what is felt by others, especially considering what if we are in the other person's position. Empathy is very necessary in the process of interpersonal communication to prevent communication barriers with other people. One form of empathy for the interlocutor is the communicator listens attentively to the other person and there is eye contact. In this research, it was found that all respondents listened attentively while others were talking, saw the other person when they were listening and had made eye contact with the other person.

Based on the seven components of effective communication in this research it was found that the criteria of the suitability of the message with the needs of respondents, the 
use of communication channels, empathy attitude above $81,5 \%$, while the components of message clarity, completeness of planning and organizing messages, feedback and understanding of messages and content the message delivered is still less than $65 \%$. This condition can occur because of the lack of the ability of respondents in effective communication applications, given the dominant material re-training activities on tuberculosis material. The material of effective communication is still lacking because only one session is given on day 3 and role play is carried out on day four. Though communication is a very important capability for cadres who will find suspects and provide assistance to tuberculosis patients. Communication is the exchange of information between people by sending and receiving it through speaking, writing or by using any other media. Clear communication means that information is conveyed effectively among people (Sibiya, 2018). Attitudes, emotions, knowledge, and credibility of the communicator and with the recipient, greatly influence communication (Cohn, 2019)

\section{REFERENCES}

Aisyiyah. (2017). Program TB-HIV Care. Retrieved from http://www.aisyiyah.or.id/id/page/kerja sama.html

Akilandeswari, V., Kumar, A. D., Freeda, A. P., \& Kumar, S. N. (2015). Elements of Effective Communication. New Media and Mass Communication 37, 44-47. Retrieved from https://www.iiste.org/Journals/index.p hp/NMMC/article/view/22833

Berman, A. (2016). fundamentals of nursing : concepts, practice, and process / (Tenth edit). Julie Levin Alexander.

Cohn, K. H. (2019). Strategies for Career Success; Developing Effective
It can be said that $\mathrm{TB}$ cadre re-training participants who are able to communicate effectively based on all components of effective communication generally reach $59.3 \%$. This condition shows the low ability of TB cadres (Tuberkuosis) in effective communication, so that it will affect the ability of cadres in carrying out the task.

\section{CONCLUSIONS AND SUGGESTIONS}

More than half of TB Aisyah cadres in Mojokerto city have effective communication skills. Only three of the seven main components of effective communication measured included: the fit of the message with the needs of the respondent, the use of the communication channel, the attitude of empathy.

Further re-training needs to be done to improve effective communication skills specifically on the components of message clarity, completeness of planning and organizing messages, feedback and understanding of the messages and the contents of messages, so that cadres are expected to be better able to carry out their duties.

Communication Skills. Journal of Oncology Praktice, 3(6). https://doi.org/10.1200/JOP.0766501 Retrieved from https://ascopubs.org/doi/pdf/10.1200/J OP.0766501

Corcoran, N. (2007). Communicating Health Strategies For Health Promotion. Sage Publication.

Dinkes. (2013). Pelatihan Kader Tuberculosis (TB) Melalui Desa Pakraman. Retrieved from https://dinkes.denpasarkota.go.id/.../Pel atihan-Kader-TuberculosisawalTBakhir-Melal...\%0A\%0A 
Bach, S., Grant, A. (2009). Communication and Interpersonal Skills for Nurses. Great Britain: Learning Matters Ltd. Retrieved from https://pdfs.semanticscholar.org/e816/e cb4fa3f6ceb5c4dd1eb22df239cb1afa6 40.pdf

Infodatin. (2018). Tuberkulosis. Retrieved from

http://www.depkes.go.id/resources/do wnload/pusdatin/infodatin/infodatin tuberkulosis 2018.pdf

Kemenkes. (2015). Tuberkulosis temukan obati sampai sembuh. Retrieved from http://www.depkes.go.id/article/view/1 5041400002/tuberkulosis-temukanobati-sampai-sembuh.html

KNCV. (2018). Area Prioritas Challenge TB. Retrieved from https://www.kncv.or.id/id/pendekatanctb.html

Management, N. I. of A. E. (2013). Training Program on Effective Communication. Retrieved from https://www.manage.gov.in/studymate rial/EC.pdf

Palupi, J., Hidayat, M. F., Subiyantini, D., \& Rizki, P. (2016). Keterampilan Komunikasi Interpersonal Mahasiswa Tingkat Satu. Retrieved from eprints.umk.ac.id/6115/5/3_Ketrampila n_Komunikasi.pdf

Rickheit, G. (Ed.) \& Strohner, H. (Ed.) (2008). Handbook of Communication Competence. Berlin, Boston: De Gruyter Mouton. https://doi.org/10.1515/978311019900 0 Retrieved 26 Jul. 2019, from https://www.degruyter.com/view/prod uct/19365

Salija, K., Muhayyang, M., \& Rasyid, M. A. (2018). Interpersonal Communication: A Social Harmony Approach (Second). Makasar: UNM. Retrieved from http://ebook.unm.ac.id/?wpfb_dl=80
Sibiya, M. N. (March 21st 2018). Effective Communication in Nursing, Nursing, Nilgun Ulutasdemir, IntechOpen, DOI: 10.5772/intechopen.74995. Available from:

https://www.intechopen.com/books/nu rsing/effective-communication-innursing

Suara Muhammadiyah. (2019). Aisyiyah Eliminasi TB-HIV Berbasis Komunitas. Retrieved from http://www.suaramuhammadiyah.id/20 19/03/15/aisyiyah-eliminasi-tb-hivberbasis-komunitas/ 